\title{
The Influence of Location and Selling Price on Purchasing Decisions at PT. Gapura Prima Group
}

\author{
Iis Noviyanti', Feb Amni Hayati \\ ${ }_{1.2}$ Universitas Pamulang \\ E-mail: Noviya.115@gmail.com
}

(Received: December-2018; Reviewed: January-2019; Accepted: February-2019;

Avalaibel Online: February-2019; Published: March-2019)

c) (7) (2) This is an open access article distributed under the Creative Commons Attribution License
CC-BY-NC-4.0 (C2019 by author (https://creativecommons.org/licenses/by-nc/4.0/)

\begin{abstract}
Today's economic development is marked by the emergence of various forms of the property very quickly and continuously. This study aims to determine the effect of location and selling price on the purchasing decision of Bailey's City Ciputat Apartment Unit at PT. Gapura Prima Group. The method used was explanatory research with a sample of 86 respondents. The analysis technique uses statistical analysis with regression testing, correlation, determination, and hypothesis testing. The results of this study location have a significant effect on purchasing decisions of $42.0 \%$, the hypothesis test obtained significance of $0,000<0.05$. The selling price has a significant effect on the purchase decision of $46.9 \%$, the hypothesis test obtained a significance of $0,000<0.05$. Location and selling price simultaneously have a significant effect on the purchase decision of Bailey's City Ciputat Apartment Unit by 56.2\%, the hypothesis test obtained significance of $0,000<0.05$.
\end{abstract}

Keywords: Location; selling price; purchase decision.

\section{INTRODUCTION}

Every company is demanded to always continue to run every business and manage its management well (Assauri, 2008; Fahmi, 2014; Kotler \& Keller, 2009). The aim of the company is to maintain survival for development and make a profit (Arian, 2014; Rudianto, 2013). Today's economic development is marked by the emergence of various forms of the property very quickly and continuously. Various products that were previously unimaginable, are now widely known by the public.

The survey conducted by www.rumah.com explained that there were as many as three main factors being the property purchase made by Indonesians, namely from the location of the property, the price offered by the developer, and the potential of the property to be leased back (investment). 
Location factors become the main factors, among others, because the level of congestion is increasingly increasing in Jakarta, thus making people look for alternative access to their activities. Not only traffic, proximity to public facilities such as health facilities, education, shopping centers, entertainment venues, toll roads, and business centers are also a matter of consumer consideration. Getting closer to public facilities will make it easier for consumers to decide to buy the property. Site selection has a strategic function because it can help determine the achievement of business entity goals. Location is referring to various marketing activities that seek to facilitate and facilitate the delivery or distribution of goods and services from producers to consumers (Nurbaity L, 2014; Peter \& Olson, 2014; Sutisna, 2003; Tjiptono, 2015). According to (Lupiyoadi, 2011) location is a decision made by the company regarding where the operations and staff will be located. The importance of location for service companies depends on the type and degree of interaction involved. A location is a place where the company's products are located. The location will play a role in determining the success and achievement of business because location will affect the size of the potential market that can be achieved by a company (Aprisal, 2017; Ghanimata, 2012; Rofiq \& Hufron, 2018; Sinambow \& Trang, 2015)

Price is also one of the other main factors in this regard is considered important especially because the current price level both in terms of residential and office units is also increasingly expensive. Price is the amount of money billed for a product and service or the amount of value exchanged by customers to obtain benefits from owning or using the product or service (Adisaputro, 2010; Lupiyoadi, 2011; Swastha, Basu, 2014). According to (Kotler \& Keller, 2009) Price is the amount of money that customers must pay for a product. Interpreting that the price is a sum of money is needed for a combination of goods and their services. More broadly, price is the amount of value given by a customer to benefit from owning or using a product or service. In purchasing decisions for a product, the role of the price is very important. Therefore, companies must be able to create pricing strategies that not only benefit the company but also satisfy their customers. Consumer decisions are motives or incentives that arise against something where a buyer makes a purchase due to the needs and desires. The purchasing decision is the decision process stage where the consumer actually purchases the product. Consumers as the main actors in the buying process are always the concern of producers (Kotler dan Amstrong, 2008).

The number of apartments sold in 2018 is 86 units/space. This condition has not yet reached the target set by the company. From what has been targeted and the realization that there is greatly decreased. This condition is caused by the factors that influence consumers in making a decision to buy Bailey's City Ciputat Apartment, one of which is the increasing number of competitors in the Ciputat area, which makes Bailey's City Apartment's sales decrease. Based on the location plan and the price table, this indicates that the number of sales of Bailey's City Ciputat Apartments has decreased.

\section{METHOD}

This research is quantitative research. The type of research used is associative, where the aim is to find out the relationship between variables. The population in this study amounted to 86 customers of PT. Gapura Prima Group. The sampling technique in this study is saturated sampling, where all members of the population are sampled. Thus the sample in this study amounted to 86 respondents. In analyzing the data used the instrument test, classical assumption test, regression, coefficient of determination and hypothesis testing. 


\section{RESULT AND DISCUSSION}

Gapura Prima Group is a company engaged in the property business. The product being marketed is an apartment or vertical residence as a residence or investment needed by everyone. That is, the need for these products never stops (repeat business) with increasing birth rates and increasing population and limited land to create housing in large numbers.

\section{Descriptive Analysis}

This test used to determine the highest minimum and maximum scores, ratting scores and standard deviations of each variable. The results are as follows:

Table 1.

Descriptive Statistics Analysis Results

\section{Descriptive Statistics}

\begin{tabular}{lr|r|r|r|r}
\hline & N & Minimum & Maximum & \multicolumn{1}{c}{ Mean } & \multicolumn{1}{c}{ Std. Deviation } \\
\hline Location (X1) & 86 & 30 & 48 & 38.17 & 4.004 \\
\hline Selling Price (X2) & 86 & 30 & 46 & 38.28 & 3.668 \\
\hline Purchase Decision (Y) & 86 & 32 & 47 & 39.02 & 3.505 \\
\hline Valid N (listwise) & 86 & & & & \\
\hline
\end{tabular}

The location obtained a minimum variance of 30 and a maximum variance of 48 with a rating score of 38.17 with a standard deviation of 4.004 . The selling price obtained a minimum variance of 30 and a maximum variance of 46 with a rating score of 38.28 with a standard deviation of 3.668. The purchase decision obtained a minimum variance of 32 and a maximum variance of 47 with a rating score of 39.02 with a standard deviation of 3.505.

\section{Multiple Regression Analysis}

This regression test is intended to determine changes in the dependent variable if the independent variable changes. The test results are as follows:

Table 2.

Multiple Regression Testing Results

\section{Coefficients $^{\mathbf{a}}$}

\begin{tabular}{|c|c|c|c|c|c|c|}
\hline \multirow{2}{*}{\multicolumn{2}{|c|}{ Model }} & \multicolumn{2}{|c|}{$\begin{array}{l}\text { Unstandardized } \\
\text { Coefficients }\end{array}$} & \multirow{2}{*}{$\begin{array}{c}\text { Standardized } \\
\text { Coefficients } \\
\text { Beta } \\
\end{array}$} & \multirow[b]{2}{*}{$\mathrm{t}$} & \multirow[b]{2}{*}{ Sig. } \\
\hline & & B & Std. Error & & & \\
\hline 1 & (Constant) & 9.445 & 2.878 & & 3.282 & .002 \\
\hline & Location (X1) & .329 & .078 & .376 & 4.197 & .000 \\
\hline & Price Selling (X2) & .445 & .086 & .465 & 5.198 & .000 \\
\hline
\end{tabular}

a. Dependent Variable: Purchase Decision (Y)

Based on the test results in the above table, the regression equation $\mathrm{Y}=9.445+0.329 \mathrm{X} 1+$ $0.455 \times 2$ is obtained.

A constant of 9,445 means that if there is no location and selling price, then there is a purchase decision value of 9,445 points. The location regression coefficient is 0.329 , this number is positive, meaning that each location has an increase of 0.329 , the purchasing decision will also increase by 0.329 points. The selling price regression coefficient is 0.455 , this number is positive, meaning that every time there is an increase in the selling price of 0.455 , the purchase decision will also increase by 0.455 points. 


\section{Correlation Coefficient Analysis}

Correlation coefficient analysis is intended to determine the level of strength of the relationship of the independent variable on the dependent variable both partially and simultaneously. The test results are as follows:

Table 3.

Test Results Correlation Coefficient Locations Against Purchasing Decisions.

\begin{tabular}{llr|r}
\hline \multicolumn{1}{c}{ Correlations $^{\mathbf{b}}$} & & \\
\hline & & Location (X1) & $\begin{array}{r}\text { Purchasing Decision } \\
\text { (Y) }\end{array}$ \\
\hline Location (X1) & Pearson Correlation & 1 & $.648^{* *}$ \\
\cline { 2 - 4 } & Sig. (2-tailed) & & .000 \\
\hline Purchasing Decision (Y) & Pearson Correlation & $.648^{* *}$ & 1 \\
\cline { 2 - 4 } & Sig. (2-tailed) & .000 & \\
\hline
\end{tabular}

**. Correlation is significant at the 0.01 level (2-tailed).

b. Listwise $\mathrm{N}=86$

Based on the test results obtained by the correlation value of 0.648 means that the location has a strong relationship with the purchase decision.

Table 4

Test Results Correlation Coefficient Selling Price Against the Purchase Decision.

Correlations $^{\mathbf{b}}$

\begin{tabular}{llr|r}
\hline & & $\begin{array}{c}\text { Selling Price } \\
(\mathrm{X} 2)\end{array}$ & Purchasing Decision (Y) \\
\hline Selling Price (X2) & Pearson Correlation & 1 & $.685^{* *}$ \\
\cline { 2 - 4 } & Sig. (2-tailed) & & .000 \\
\hline Purchasing Decision (Y) & Pearson Correlation & $.685^{* *}$ & 1 \\
\cline { 2 - 4 } & Sig. (2-tailed) & .000 & \\
\hline
\end{tabular}

**. Correlation is significant at the 0.01 level (2-tailed).

b. Listwise $\mathrm{N}=86$

Based on the test results obtained by the correlation value of 0.685 means that the selling price has a strong relationship with the purchase decision.

Table 5.

Simultaneous Correlation Test Results Location and Selling Price Simultaneously on Purchasing Decisions.

Model Summary

\begin{tabular}{llr|rrr}
\hline & & \multicolumn{2}{c}{$\begin{array}{c}\text { Adjusted R } \\
\text { Square }\end{array}$} & \multicolumn{2}{c}{$\begin{array}{c}\text { Std. Error of the } \\
\text { Estimate }\end{array}$} \\
\hline 1 & $\mathrm{R}$ & \multicolumn{2}{|c|}{ R Square } & \multicolumn{2}{c}{ Square } \\
\hline
\end{tabular}

a. Predictors: (Constant), Selling Price(X2), Location(X1)

Based on the test results obtained by a correlation value of 0.750 means that the location and selling price simultaneously have a strong relationship with the purchase decision. 


\section{Analysis of the Coefficient of Determination}

Analysis of the coefficient of determination is intended to determine the percentage of influence of the independent variable on the dependent variable either partially or simultaneously. The test results are as follows:

Table 6

Results of Testing the Location Determination Coefficient on Purchasing Decisions.

\begin{tabular}{|c|c|c|c|c|}
\hline \multicolumn{5}{|c|}{ Model Summary } \\
\hline Model & $\mathrm{R}$ & R Square & $\begin{array}{l}\text { Adjusted R } \\
\text { Square }\end{array}$ & $\begin{array}{l}\text { Std. Error of the } \\
\text { Estimate }\end{array}$ \\
\hline 1 & $.648^{a}$ & .420 & .413 & 2.685 \\
\hline
\end{tabular}

a. Predictors: (Constant), Location (X1)

Based on the test results obtained a determination value of 0.420 means that the location has an influence contribution of $42.0 \%$ to the purchase decision.

Table 7.

Test Result Determination Coefficient Test Results on Purchasing Decisions.

\begin{tabular}{|c|c|c|c|c|}
\hline \multicolumn{5}{|c|}{ Model Summary } \\
\hline Model & $\mathrm{R}$ & R Square & $\begin{array}{c}\text { Adjusted R } \\
\text { Square }\end{array}$ & $\begin{array}{l}\text { Std. Error of the } \\
\text { Estimate }\end{array}$ \\
\hline 1 & $.685^{\mathrm{a}}$ & .469 & .463 & 2.568 \\
\hline
\end{tabular}

Based on the test results obtained a determination value of 0.469 means that the selling price has an influence contribution of $46.9 \%$ to the purchase decision.

Table 8

Test Results for the Determination Coefficient of Location and Selling Price on Purchasing Decisions.

\section{Model Summary}

\begin{tabular}{|c|c|c|c|c|}
\hline Model & $\mathrm{R}$ & R Square & $\begin{array}{c}\text { Adjusted R } \\
\text { Square }\end{array}$ & $\begin{array}{l}\text { Std. Error of the } \\
\text { Estimate }\end{array}$ \\
\hline 1 & $.750^{\mathrm{a}}$ & .562 & .552 & 2.346 \\
\hline
\end{tabular}

Based on the test results obtained a determination value of 0.562 means that the location and selling price simultaneously have an influence contribution of $56.2 \%$ to the purchase decision, while the remaining $43.8 \%$ is influenced by other factors. 


\section{Hypotesis Test}

Hypothesis testing with a t-test is used to find out which partial hypotheses are accepted.

Table 9.

Results of the Location Hypothesis Test Against Purchasing Decisions.

\section{Coefficients $^{\mathrm{a}}$}

\begin{tabular}{|c|c|c|c|c|c|c|}
\hline \multirow{2}{*}{\multicolumn{2}{|c|}{ Model }} & \multicolumn{2}{|c|}{$\begin{array}{l}\text { Unstandardized } \\
\text { Coefficients }\end{array}$} & \multirow{2}{*}{$\begin{array}{l}\text { Standardized } \\
\text { Coefficients } \\
\text { Beta }\end{array}$} & \multirow[b]{2}{*}{$\mathrm{t}$} & \multirow[b]{2}{*}{ Sig. } \\
\hline & & $\mathrm{B}$ & Std. Error & & & \\
\hline \multirow[t]{2}{*}{1} & (Constant) & 17.373 & 2.792 & & 6.222 & .000 \\
\hline & Location (X1) & .567 & .073 & .648 & 7.795 & .000 \\
\hline
\end{tabular}

a. Dependent Variable: Purchasing Decision (Y)

Based on the test results in the above table, the value of $t_{\text {count }}>t_{\text {table }}$ or $(7.795>1.989)$ mean there is a significant influence location on the purchasing decision.

Table 10.

Hypothesis Test Results Selling prices on purchasing decisions.

\section{Coefficients $^{\mathrm{a}}$}

\begin{tabular}{|c|c|c|c|c|c|c|}
\hline \multirow{2}{*}{\multicolumn{2}{|c|}{ Model }} & \multicolumn{2}{|c|}{$\begin{array}{l}\text { Unstandardized } \\
\text { Coefficients }\end{array}$} & \multirow{2}{*}{$\begin{array}{c}\text { Standardized } \\
\text { Coefficients } \\
\text { Beta } \\
\end{array}$} & \multirow[b]{2}{*}{$\mathrm{t}$} & \multirow[b]{2}{*}{ Sig. } \\
\hline & & $\mathrm{B}$ & Std. Error & & & \\
\hline \multirow[t]{2}{*}{1} & $\overline{(\text { Constant })}$ & 13.965 & 2.921 & & 4.782 & .000 \\
\hline & Selling Price (X2) & .655 & .076 & .685 & 8.619 & .000 \\
\hline
\end{tabular}

a. Dependent Variable: Purchasing Decision (Y)

Based on the test results in the above table, the value of $t_{\text {count }}>t_{\text {table }}$ or $(8,619>1,989)$ is obtained, thus there is a significant influence between the selling price on the buying decision

Hypothesis testing with the F test is used to find out which simultaneous hypotheses are accepted.

Table 11.

Hypothesis Test Results for Location and Selling Prices Against Purchasing Decisions.

\section{ANOVA $^{\mathrm{a}}$}

\begin{tabular}{llr|r|r|r|r}
\hline \multicolumn{1}{l}{ Model } & Sum of Squares & \multicolumn{1}{c|}{ df } & Mean Square & \multicolumn{1}{c}{ F } & \multicolumn{1}{c}{ Sig. } \\
\hline 1 & Regression & 586.953 & 2 & 293.476 & 53.301 & $.000^{\mathrm{b}}$ \\
\cline { 2 - 7 } & Residual & 457.001 & 83 & 5.506 & & \\
\cline { 2 - 7 } & Total & 1043.953 & 85 & & & \\
\hline
\end{tabular}

a. Dependent Variable: Purchasing Decision (Y)

b. Predictors: (Constant), Selling Price (X2), Location(X1)

Based on the test results in the above table, the value of $F_{\text {count }}>F_{\text {table }}$ or (53.310> 3.110) thus there is a significant influence between location and selling price on the purchase decision

\section{CONCLUSION}

Based on the results of the study, the location has a significant effect on purchasing decisions for Bailey's City Ciputat Apartment Units with an influence contribution of $42.0 \%$. Hypothesis testing obtained $t$ count $>t_{\text {table }}$ or $(7.795>1.989)$. The selling price has a significant 
effect on the decision to purchase the Ciputat Bailey's City Apartment Unit with an influence contribution of $46.9 \%$. Hypothesis testing obtained $t_{\text {count }}>t_{\text {table }}$ or $(8,619>1,989)$. Location and selling price has a significant effect on the purchase decision for Bailey's City Ciputat Apartment Unit with a contribution of $56.2 \%$ while the remaining $43.8 \%$ is influenced by other factors. Hypothesis testing obtained by the calculated $F_{\text {count }}>F_{\text {table }}$ or $(53.310>3.110)$.

\section{REFERENCES}

Adisaputro, G. (2010). Manajemen Pemasaran Analisis Untuk Perancangan Strategi Pemasaran. UPP STIM YKPN.

Aprisal, D. (2017). Pengaruh Kualitas Produk, Harga, Promosi Dan Lokasi Terhadap Keputusan Pembelian. eJournal Ilmu Administrasi Bisnis.

Arian, D. W. (2014). Manajemen Operasi Jasa. Manajemen Operasi. https://doi.org/10.1177/004057368303900411

Assauri, S. (2008). Manajemen Produksi dan Operasi. Jakarta: Lembaga Penerbit Fakultas Ekonomi Universitas Indonesia.

Fahmi, I. (2014). Manajemen Keuangan Perusahaan dan Pasar Modal. Manajemen Keuangan Perusahaan dan Pasar Modal.

Ghanimata, F. (2012). Analisis Pengaruh Harga, Kualitas Produk, Dan Lokasi Terhadap Keputusan Pembelian. Skripsi.

Kotler dan Amstrong. (2008). Prinsip-Prinsip Pemasaran Jilid I. In Erlangga.

Kotler, P., \& Keller, K. L. (2009). Manajemen pemasaran Jilid 1. In Jakarta.

Lupiyoadi. (2011). Manajemen Pemasaran Jasa Teori dan Praktik. In Salemba Empat. https://doi.org/10.1002/cb.84

Nurbaity L, A. (2014). Strategi Pemasaran dalam Persaingan Bisnis. Universitas Sumatra Utara.

Peter, J. P., \& Olson, J. C. (2014). Perilaku Konsumen dan Strategi Pemasaran. In salemba empat.

Rofiq, A., \& Hufron, M. (2018). Pengaruh Kualitas Produk, Harga Dan Lokasi Terhadap Keputusan Pembelian Di Powernoise Store Studi Kasus Pada Konsumen Powernoise Store Malang. Jurnal Ilmiah Riset Manajemen.

Rudianto. (2013). Akuntansi Manajemen Informasi untuk Pengmbilan Keputusan Strategis. In Akuntansi Manajemen.

Sinambow, S., \& Trang, I. (2015). Pengaruh Harga, Lokasi, Promosi Dan Kualitas Layanan Terhadap Keputusan Pembelian Pada Toko Komputer Game Zona Mega Mall Manando. Emba Issn 2303-11.

Sutisna. (2003). Perilaku Konsumen: Teori dan penerapannya dalam Pemasaran. Ghalia Indonesia, Jakarta. https://doi.org/10.1007/BF01013984

Swastha, Basu, I. (2014). Manajemen Pemasaran Modern. In Liberty, Yogyakarta. https://doi.org/10.1017/CBO9781107415324.004

Tjiptono, F. (2015). Strategi Pemasaran. Edisi 4. In Andi: Yogyakarta. 
176 | Pinisi Discretion Review

Volume 2, Issue 2, March, 2019 Page. 169- 176 